\title{
Effect of a new antitranspirant on the physiology and water use efficiency of soybean under different irrigation rates in an arid region
}

\author{
Shasha $\mathrm{JI}^{1}$, Ling TONG $(\bowtie)^{1}$, Fusheng $\mathrm{LI}^{2}$, Hongna $\mathrm{LU}^{1}$, Sien $\mathrm{LI}^{1}$, Taisheng DU ${ }^{1}$, Youjie WU ${ }^{1}$ \\ 1 Center for Agricultural Water Research in China, China Agricultural University, Beijing 100083, China \\ 2 College of Agriculture, Guangxi University, Nanning 530005, China
}

\begin{abstract}
Antitranspirants are exogenous substances applied to leaves to reduce luxury transpiration by regulating stomatal conductance to increase water use efficiency (WUE). A cheap and environmentally-friendly antitranspirant, FZ, was newly developed, extracted mainly from Alhagi sparsifolia. Its effects on soybean water use were investigated in a field experiment using the locally-used irrigation rate and a low irrigation rate (The lower and upper limit of irrigation is $40 \%-70 \%$ of field capacity). Foliar application of FZ and measurement of leaf physiological characteristics, final biomass, seed yield and water use efficiency were carried out during the pod bearing and pod filling stages of drip-irrigated soybean with film-mulching. Under the low irrigation rate, leaf stomatal conductance $\left(\mathrm{g}_{\mathrm{s}}\right)$ and transpiration rate $(\mathrm{Tr})$ decreased significantly by $7 \mathrm{~d}$ after spraying, but photosynthesis (Pn) and instantaneous water use efficiency $\left(W_{U} E_{\text {in }}\right)$ were not significantly affec ted. The stomatal frequency, stomatal aperture, $\mathrm{g}_{\mathrm{s}}, \mathrm{Tr}$ and $\mathrm{Pn}$ decreased by $1 \mathrm{~d}$ after spraying, without significantly increasing $\mathrm{WUE}_{\text {in }}$. However, applying FZ during the pod bearing and pod filling stages did not significantly affect the final biomass, water consumption, seed yield and WUE of soybean. Under the locally-used irrigation rate, applying FZ increased the activities of superoxide dismutase and peroxidase in the leaves by $38 \%$ and $33 \%$, respectively, but did not significantly affect $g_{s}, T r, P n$, stomatal aperture and stomatal frequency. Applying FZ three times during pod bearing and pod filling stages enhanced seed yield and WUE by $24 \%$ and $21 \%$, respectively, but did not significantly affect the final biomass and water consumption. Therefore, seed yield and WUE of soybean were significantly increased by foliar application of FZ during the pod bearing and pod filling stages under the locally-
\end{abstract}

Received December 9, 2016; accepted February 27, 2017

Correspondence: tongling2001@cau.edu.cn used irrigation rate in arid region, but applying FZ did not have a positive effect on water use efficiency of soybean under a low irrigation rate.

Keywords antitranspirant, soybean, water deficit, leaf gas exchange, enzymes activities, water consumption, seed yield

\section{Introduction}

Reducing crop luxury transpiration is important in improving water productivity ${ }^{[1]}$. The sensitivity of leaf photosynthesis $(\mathrm{Pn})$ and transpiration (Tr) to stomatal conductance $\left(\mathrm{g}_{\mathrm{s}}\right)$ differs. Leaf $\mathrm{Pn}$ and $\mathrm{Tr}$ increase with increasing $g_{s}$, but when leaf $g_{s}$ reaches a certain value, $P n$ does not obviously increase further but $\operatorname{Tr}$ increases linearly ${ }^{[2]}$, so crop luxury transpiration may occur. A balance between leaf photosynthesis and transpiration can be achieved by adjusting the stomatal behavior to the optimal status using exogenous substances (antitranspirants), which lead to an increase in water use efficiency (WUE) at the leaf level. Also, antitranspirants can increase leaf superoxide dismutase (SOD) and peroxidase (POD) activities to improve drought resistance in $\mathrm{crops}^{[3-8]}$, and alleviate the negative effects of drought on crop production $^{[9-14]}$.

The antitranspirants include phenylmercuric acetate (PMA) ${ }^{[15-26]}$, salicylic acid (SA) ${ }^{[4,6,8,15,27-29]}$, abscisic acid $(\mathrm{ABA})^{[3,5,9,15,16,30-40]}$, kaolin ${ }^{[14,24,41-44]}$, Vapor $\operatorname{Gard}^{[39,45-48]}$ and some others. The effect of an antitranspirant is influenced by its chemistry, soil moisture conditions and spraying period ${ }^{[6,9,10,12,37,48-54]}$. Under a low irrigation rate, spraying kaolin on the grape significantly reduced leaf $\mathrm{g}_{\mathrm{s}}$ and $\mathrm{Tr}$, and improved leaf WUE, while there are no significant effect under a high irrigation rate ${ }^{[14]}$. Spraying ABA at different growth stages has different effects on the grain yield of wheat. Spraying 
$\mathrm{ABA}$ at the flowering stage significantly increased grain yield but there was no significant effect on grain yield when ABA was applied at the grain filling stage ${ }^{[9,38]}$.

Although PMA, SA and ABA had better control of stomatal behavior ${ }^{[17,28,38]}$, there was a negative effect of PMA and SA on leaves ${ }^{[15,19,22]}$. And ABA is uneconomic to apply in commercial production due to the high price $^{[5,15]}$. In this study, alkaloid essential oil was extracted from Alhagi sparsifolia, a drought-resistant plant widely distributed in the desert area, and then elements such as zinc, boron, nitrogen, phosphorus and potassium were added to make a cheap and environmentally-friendly antitranspirant, FZ (Xinjiang Huitong Humic Acid Co., Ltd., China).

Agriculture in arid regions largely depends on irrigation because of the shortage of water resources ${ }^{[55,56]}$, and the crop is often subjected to drought stress during the growth period. It is hypothesized that foliar application of FZ can produce positive effects on water use efficiency of soybean in an arid region. To determine the effects of FZ, two irrigation rates were employed in this study: the locallyused irrigation rate and a low irrigation rate. The objectives were to investigate the effects of spraying FZ from the pod bearing stage to pod filling stage on leaf $g_{s}, \mathrm{Pn}, \mathrm{Tr}$, SOD and POD, seed yield and water use efficiency of soybean under different irrigation rates, and then evaluate the effects of FZ on drip irrigated soybean in the arid region, to provide a scientific basis for application of FZ.

\section{Materials and methods}

\subsection{Experimental site and materials}

A field experiment was conducted during May to September, 2013 at Shiyanghe Experimental Station for Water-saving in Agriculture and Ecology of China Agricultural University $\left(37^{\circ} 52^{\prime} \mathrm{N}, 102^{\circ} 50^{\prime} \mathrm{E}, 1581 \mathrm{~m}\right)$ in Gansu Province in Northwest China. The site has a typical temperate continental climate, with favorable light and temperature, a large difference between day and night temperatures, over $3000 \mathrm{~h}$ of average annual sunshine duration, 150 frost-free days, and over 3550 degree-day of annual accumulated temperature (over $0^{\circ} \mathrm{C}$ ), while annual precipitation is $164.5 \mathrm{~mm}$ and annual pan evaporation is $2000 \mathrm{~mm}$ from 1951 to $2013^{[57]}$. The soil texture is a sandy loam to a depth of $0.6 \mathrm{~m}$, with a mean soil dry bulk density of $1.48 \mathrm{~g} \cdot \mathrm{cm}^{-3}$ and soil water content at field capacity of $0.26 \mathrm{~m}^{3} \cdot \mathrm{m}^{-3}$, respectively. Glycine max $\mathrm{cv}$. Zhonghuang 30 is widely planted in the area. The active ingredients and contents of FZ are shown in Table 1. Potassium, nitrogen, phosphorus are the main nutrient elements for growth and development of soybean. The glycinebetaine and proline improves photosynthesis activity, nitrogen fixation and plant stress tolerance ${ }^{[7,58]}$, and abscisic acid (ABA) induces stomatal closure ${ }^{[30]}$.

Table 1 The main constituents of FZ

\begin{tabular}{lc}
\hline Ingredient & Content \\
\hline Potassium $/\left(\mathrm{mg} \cdot \mathrm{g}^{-1}\right)$ & 70.6 \\
Nitrogen $/\left(\mathrm{mg} \cdot \mathrm{g}^{-1}\right)$ & 4.2 \\
Phosphorus $/\left(\mathrm{mg} \cdot \mathrm{g}^{-1}\right)$ & 0.13 \\
Calcium $/\left(\mu \mathrm{g} \cdot \mathrm{g}^{-1}\right)$ & 60 \\
Glycinebetaine $/\left(\mathrm{mg} \cdot \mathrm{mL}^{-1}\right)$ & 9.2 \\
Proline $/\left(\mathrm{mg} \cdot \mathrm{mL}^{-1}\right)$ & 0.5 \\
Abscisic acid $/\left(\mu \mathrm{g} \cdot \mathrm{mL}^{-1}\right)$ & 2.25 \\
\hline
\end{tabular}

\subsection{Experimental design}

The field experiment was conducted with two irrigation rates, i.e., the locally-used irrigation rate (W1) and a low irrigation rate (W2). No irrigation was applied during the maturation period. During other growth stages, W1 and W2 were irrigated on the same day when the soil water content in W2 reached about $40 \%$ of field capacity. The irrigation amounts for $\mathrm{W} 1$ and $\mathrm{W} 2$ were determined by the upper limits set at $90 \%$ and $70 \%$, respectively. The irrigation amount during each growth stage is shown in Table 2. Antitranspirant FZ, or an equal amount of water (CK), were sprayed on W1 and W2. Four treatments were applied with three replicates each, with a total of 12 plots randomly arranged. FZ was evenly sprayed on both sides of soybean leaves at a concentration of $3 \mathrm{~g} \cdot \mathrm{L}^{-1}$ applying $10 \mathrm{~L}$ per plot. $\mathrm{FZ}$ was applied during the pod bearing stage (21 July), early pod filling stage (8 August) and late pod filling stage (24 August) at about $8 \mathrm{pm}$.

Each plot was $25 \mathrm{~m}^{2}(5 \mathrm{~m} \times 5 \mathrm{~m})$ with $1 \mathrm{~m}$ wide buffers between each plot. The soybean crop was irrigated by a drip irrigation system under film mulching. The drip irrigation lines (interal inlay drip tape, drip emitters $30 \mathrm{~cm}$, flow rate $2 \mathrm{~L} \cdot \mathrm{h}^{-1}$, thickness $0.2 \mathrm{~mm}$, diameter $16 \mathrm{~mm}$, Dayu Water Group Co., Ltd.) were $1 \mathrm{~m}$ apart. A white

Table 2 Irrigation amount at different growth stages of soybean $(\mathrm{mm})$

\begin{tabular}{|c|c|c|c|c|c|c|}
\hline \multirow[b]{2}{*}{ Treatment } & \multicolumn{2}{|c|}{ Vegetative growth stage } & \multicolumn{4}{|c|}{ Reproductive growth stage } \\
\hline & $\begin{array}{l}\text { Establishment } \\
(05 / 12-05 / 21)\end{array}$ & $\begin{array}{c}\text { Branching } \\
(05 / 21-06 / 26)\end{array}$ & $\begin{array}{c}\text { Flowering } \\
(06 / 26-07 / 21)\end{array}$ & $\begin{array}{l}\text { Pod bearing } \\
(07 / 21-08 / 08)\end{array}$ & $\begin{array}{l}\text { Pod filling } \\
(08 / 08-09 / 02)\end{array}$ & $\begin{array}{c}\text { Maturity } \\
(09 / 02-09 / 18)\end{array}$ \\
\hline W2 & - & 35 & 45 & 50 & 50 & - \\
\hline W1 & - & 50 & 75 & 70 & 75 & - \\
\hline
\end{tabular}

Note: Sowing, 10 May; $90 \mathrm{~mm}$ irrigation for all treatments for seedling emergence on 10 May; no irrigation was applied from September of previous year. 
polyethylene film ( $90 \mathrm{~cm}$ wide, $0.008 \mathrm{~mm}$ thick) was laid over each drip irrigation line to reduce evaporation. The drip line was at the center of each plastic film, with $10 \mathrm{~cm}$ bare soil between the strips of plastic films. Two rows of soybean were planted per strip of film, at $20 \mathrm{~cm}$ from the drip line and $25 \mathrm{~cm}$ from the edge of the film. The planting density was 250000 plants per hectare with a plant spacing of $15 \mathrm{~cm}$ and row spacing of $50 \mathrm{~cm}$. Before laying the drip irrigation system and film mulching, each plot was fertilized with $525 \mathrm{~kg} \cdot \mathrm{hm}^{-2}$ of diammonium phosphate and $225 \mathrm{~kg} \cdot \mathrm{hm}^{-2}$ of potassium sulfate. The soybean seed was sown on 10 May and all treatments irrigated on 10 May with $90 \mathrm{~mm}$ of water to promote seedling emergence. The seedlings were thinned on 5 June, with two healthy seedlings per hole. Other management practices were consistent with standard local practice.

\subsection{Measurements}

\subsubsection{Physiological parameters}

Leaf gas exchange: four fully developed upper leaves from healthy plants in each treatment were randomly selected, and $\mathrm{g}_{\mathrm{s}}$, Tr and Pn measured using an LI-6400 portable photosynthesis system (LI-COR, Inc., Lincoln, NE, USA) between 10 and $11 \mathrm{am}$. Leaf instantaneous water use efficiency $\left(\mathrm{WUE}_{\text {in }}\right.$ ) was calculated as the ratio of $\mathrm{Pn}$ and $\mathrm{Tr}$.

Stomatal aperture: the stomatal aperture was determined by a silicone rubber impression method ${ }^{[59]}$. A solution of collodion was applied in the same position on the abaxial side of soybean leaves, then after drying the leaves were torn slowly with transparent tape and stuck to a microscope slide. Three specimens were made from three randomly selected leaves from each treatment, and 10 microscopic fields were randomly selected to take pictures for each specimen using a biological microscope (Motic BA210, Motic China Group Co., Ltd, Xiamen, China) then enlarged 600 times. The number and width of stomata in each field were determined using the Motic Images Plus 2.0 software. The sampling was done on the same day as the measurements of leaf gas exchange.

Enzyme activity: eight holes on the two sides of the main vein of a soybean leaf were symmetrically taken using a punch with the inner diameter of $15 \mathrm{~mm}$ for measuring enzyme activity. Four replicate samples were taken for each treatment. The activities of SOD and POD were measured by the nitro blue tetrazolium reduction method and guaiacol method, respectively ${ }^{[60]}$. The samples were taken at $6 \mathrm{pm}$ on the same day as the measurements of leaf gas exchange.

\subsubsection{Soil water content}

Two PVC access tubes were installed in the film-mulched soil of each plot. Volumetric soil water content was measured by Diviner 2000 system (Sentek Pty Ltd., Adelaide, Australia) at intervals of $0.1 \mathrm{~m}$ to a depth of $0.6 \mathrm{~m}$, and calibrated using gravimetric soil water content. Measurements were made every 7-10 d, and additional measurements were made before and after each irrigation and rainfall event. The soil water content of $\mathrm{W} 1$ and $\mathrm{W} 2$ were $18.8 \%, 20.1 \%, 23.4 \%$ and $15.3 \%, 16.1 \%, 18.2 \%$, respectively, when FZ was applied on 21 July, 8 August, 24 August.

\subsubsection{Biomass}

Biomass refers to total dry mass of leaves, stems and pods per plant at harvest. Three plants were randomly taken for each plot, and leaves, stems and pods were put into separate envelopes. These samples were first dried at $105^{\circ} \mathrm{C}$ for $30 \mathrm{~min}$, and then dried at $80^{\circ} \mathrm{C}$ to constant mass.

\subsubsection{Seed yield}

Seed yield refers to dry seed mass at harvest. Two sampling areas $(1 \mathrm{~m} \times 1 \mathrm{~m})$ were randomly selected from each plot and the average value was converted to dry seed mass per hectare of this plot. The seed yield for each treatment was calculated from the average of three replicates. WUE is the ratio of seed yield to total water consumption.

\subsection{Data analysis}

Simple statistical analysis and plotting were performed using Microsoft Excel 2010 (Microsoft, Redmond, WA, USA). Analysis of variance was performed using the generalized linear model procedure of SPSS 19.0 version software (IBM, Armonk, NY, USA). All the treatment means were compared for significant differences using Fisher's LSD test $(P \leqslant 0.05)$.

\section{Results and discussion}

3.1 Effect of antitranspirant, FZ, on leaf superoxide dismutase and peroxidase activities under different irrigation rates

Figure 1 shows the variation in leaf SOD and POD activities by $1 \mathrm{~d}$ after spraying $\mathrm{FZ}$ during the pod bearing stage of soybean under different irrigation rates. Under W1, leaf SOD and POD activities were $318 \mathrm{U} \cdot \mathrm{g}^{-1}$ and $592 \mathrm{U} \cdot \mathrm{g}^{-1} \cdot \mathrm{min}^{-1}$ for $\mathrm{CK}$, and $440 \mathrm{U} \cdot \mathrm{g}^{-1}$ and $788 \mathrm{U} \cdot \mathrm{g}^{-1} \cdot \mathrm{min}^{-1}$ for $\mathrm{FZ}$, respectively. Compared with CK, FZ significantly improved the activities of SOD and POD by $38 \%$ and $33 \%$, respectively. Similar results were found in previous studies of SA application on rice, tomato 

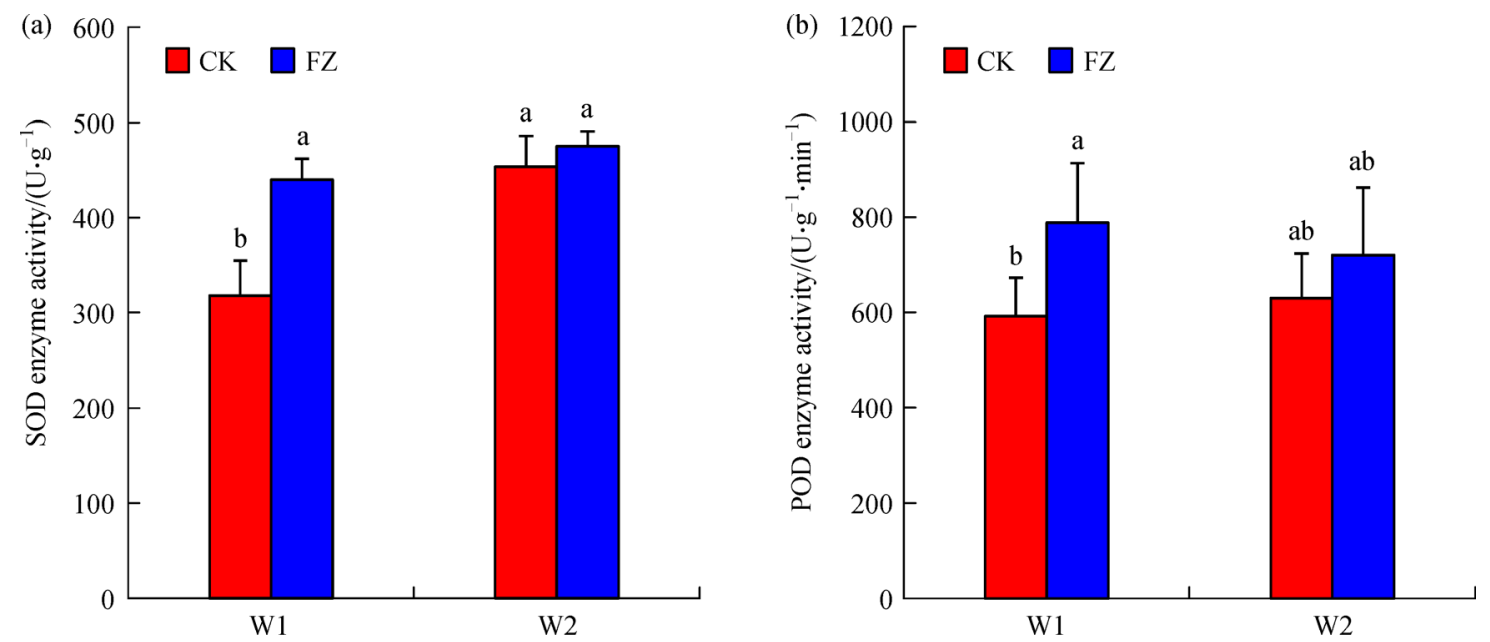

Fig. 1 Effect of foliar application of antitranspirant, FZ, during pod bearing stage on leaf superoxide dismutase (SOD) (a) and peroxidase (POD) (b) activities of soybean under different irrigation rates. W1, locally-used irrigation rate; W2, low irrigation rate; CK, water; different letters above the columns indicate significant differences at $P<0.05$ level.

and wheat ${ }^{[4,6,8,29]}$. Under W2, FZ did not significantly affect leaf SOD and POD activities. This was probably because the soil water content was reduced to $40 \%$ of field capacity under W2, which led to severe water stress, and at this time soil water content became the main factor affecting leaf SOD and POD activities. Therefore, applying FZ only increased leaf SOD and POD activities significantly under W1.

\subsection{Effect of antitranspirant FZ on leaf gas exchange under different irrigation rates}

\subsubsection{Effect of antitranspirant FZ at different growth stages} on leaf gas exchange

Figure 2 shows the variation in leaf $g_{s}, T r, P n$ and $W_{U E}$ by $1 \mathrm{~d}$ after spraying FZ during the pod bearing stage and the early and late pod filling stages of soybean. Under W1, there was no significant effect of FZ at different growth stages on leaf $\mathrm{g}_{\mathrm{s}}$, Pn and Tr, but FZ applied during the pod bearing stage significantly increased leaf $\mathrm{WUE}_{\text {in }}$ by $27 \%$ (Fig. 2d). Under W2, FZ applied at three growth stages reduced leaf $\mathrm{g}_{\mathrm{s}}, \mathrm{Tr}$ and $\mathrm{Pn}$, but the reduction in Pn was less than that in Tr, which resulted in the increase of leaf $\mathrm{WUE}_{\text {in }}$. For example, FZ applied during the pod bearing stage reduced leaf $\mathrm{Tr}$ and Pn by $37 \%$ and $22 \%$, respectively, while it increased WUE $_{\text {in }}$ by $25 \%$. FZ applied during the early pod filling stage reduced $\mathrm{g}_{\mathrm{s}}$, Tr and $\mathrm{Pn}$ by $11 \%, 4 \%$ and $9 \%$, respectively, but there was no significant effect on $\mathrm{WUE}_{\mathrm{in}}$. Therefore, leaf $W E_{\text {in }}$ under two irrigation rates increased significantly by $1 \mathrm{~d}$ after applying FZ during the pod bearing stage. This was probably because soybean needs more nutrients and water for vigorous growth during the pod bearing stage ${ }^{[61]}$, and FZ contains
$\mathrm{N}, \mathrm{P}, \mathrm{K}$ and other trace elements beneficial for soybean growth.

3.2.2 Effect of antitranspirant, FZ, during the pod bearing stage on leaf gas exchange at different times after application

Figure 3 shows the variations in leaf gas exchange at different times after applying FZ during the pod bearing stage (21 July). Under W1, applying FZ increased Pn, with this increase peaking by $7 \mathrm{~d}$ after spraying, and then gradually declining. This increase was probably because $\mathrm{N}, \mathrm{P}, \mathrm{K}$ and other trace elements in the FZ improved the activity of carboxylase per leaf area and promoted photosynthesis ${ }^{[62]}$. In addition, FZ significantly increased leaf POD activity under W1 (Fig. 1). Leaf POD can eliminate not only superoxide radicals, but also harmful $\mathrm{H}_{2} \mathrm{O}_{2}$ generated in the photosynthetic respiration process, which can improve plant photosynthesis ${ }^{[63]}$. FZ increased leaf $\mathrm{g}_{\mathrm{s}}$ by $34 \%$ by $7 \mathrm{~d}$ after spraying, but did not significantly affect $g_{s}$ by 10 and $13 \mathrm{~d}$ after spraying. Under W2, FZ significantly reduced $g_{s}$ and $\operatorname{Tr}$ by $7 \mathrm{~d}$ after spraying, but did not significantly effect $\mathrm{Pn}$ and $\mathrm{WUE}_{\text {in }}$, which was similar to the findings for applying kaolin to grapevines $^{[9]}$.

\subsection{Effect of antitranspirant FZ on leaf stomatal aperture and frequency under different irrigation rates}

Figure 4 shows the representative biomicroscope scanning images of the abaxial sides of soybean leaves by $1 \mathrm{~d}$ after applying FZ and $\mathrm{CK}$ under different irrigation rates. Figure 5 shows the effect of FZ application at the early pod filling stage on leaf stomatal aperture and frequency of soybean under different irrigation rates. The average stomatal aperture of FZ and CK leaves were 5.12 and 
W1-CK $\square$ W1-FZ $\square$ W2-CK $\square$ W2-FZ
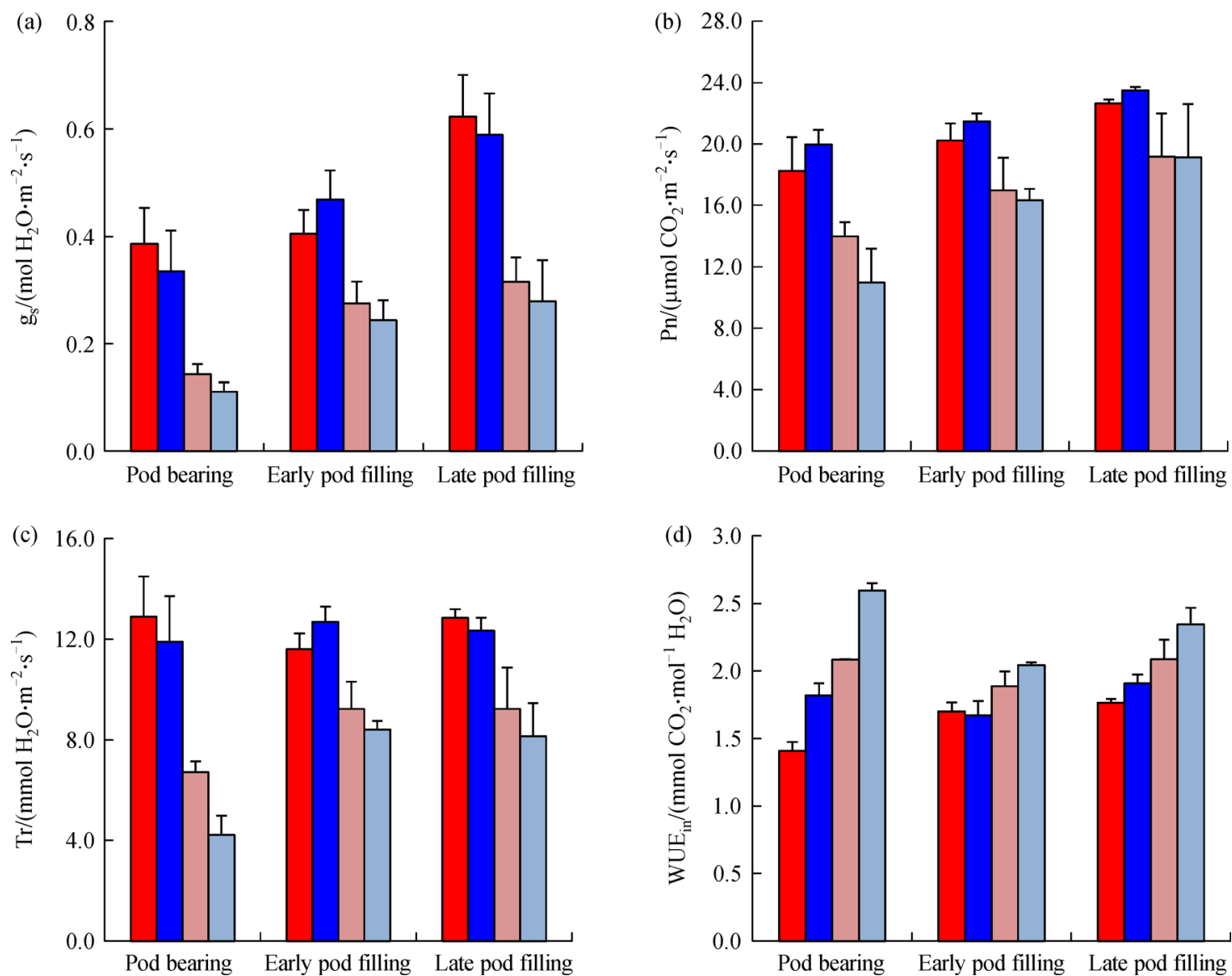

Fig. 2 Effect of foliar application of antitranspirant, FZ, at different growth stages on leaf stomatal conductance $\left(g_{s}\right)(a)$, photosynthetic rate $(\mathrm{Pn})(\mathrm{b})$, transpiration rate $(\mathrm{Tr})(\mathrm{c})$, and instantaneous water use efficiency (WUE in $)(\mathrm{d})$ of soybean by $1 \mathrm{~d}$ after spraying. W1, locallyused irrigation rate; $\mathrm{W} 2$, low irrigation rate; $\mathrm{CK}$, water.

$4.79 \mu \mathrm{m}$, and the average stomatal frequencies were 497 and $507 \mathrm{n} \cdot \mathrm{mm}^{-2}$, respectively. FZ increased leaf stomatal aperture by $7 \%$ and reduced leaf stomatal frequency by $2 \%$ compared with CK. Under W2, the average stomatal aperture of FZ and CK leaves were 3.40 and $4.05 \mu \mathrm{m}$, and the average stomatal frequencies were 309 and $359 \mathrm{n} \cdot \mathrm{mm}^{-2}$, respectively. Compared with $\mathrm{CK}, \mathrm{FZ}$ reduced the mean stomatal aperture and stomatal frequency by $16 \%$ and $14 \%$, respectively. Figure 2a shows that under W2, FZ application during the early pod filling stage reduced $\mathrm{g}_{\mathrm{s}}$ by partly closing stomata and reducing stomatal aperture, whereas under W1, FZ application during this stage increased $g_{s}$ by enlarging stomatal opening. However, there was no significant effect of applying $\mathrm{FZ}$ on $\mathrm{g}_{\mathrm{s}}$ under the two irrigation rates.

\subsection{Effect of antitranspirant FZ on final biomass, seed yield and WUE of soybean under different irrigation rates}

Final biomass, seed yield, harvest index, water consumption and WUE for all treatments are shown in Table 3. The effects of irrigation rate on final biomass, seed yield, total water consumption, harvest index, water consumption and WUE were all significant. But there were no significant effect of FZ on final biomass, seed yield, total water consumption, water consumption and WUE except harvest index. Compared with the CK, applying FZ three times under W1 from pod bearing stage to pod filling stage significantly increased the seed yield, harvest index and WUE by $23 \%, 11 \%$ and $22 \%$, respectively, but there was no significant effect under W2. The increase of WUE after applying FZ improved seed yield but did not increase water consumption under W1. There were no significant effects under W2, which was also consistent with the effect of applying FZ on leaf $\mathrm{g}_{\mathrm{s}}, \mathrm{Pn}$, $\mathrm{Tr}$ and antioxidant enzyme activities.

Under W1, the activities of SOD and POD increased after applying FZ during the pod bearing stage (Fig. 1), and promoted the photosynthesis (Fig. 2b; Fig. 3b), probably resulting in the increase in seed yield. Although leaf $\operatorname{Tr}$ temporarily increased by $7 \mathrm{~d}$ after spraying $\mathrm{FZ}$, this did not affect the biomass accumulation. This was 

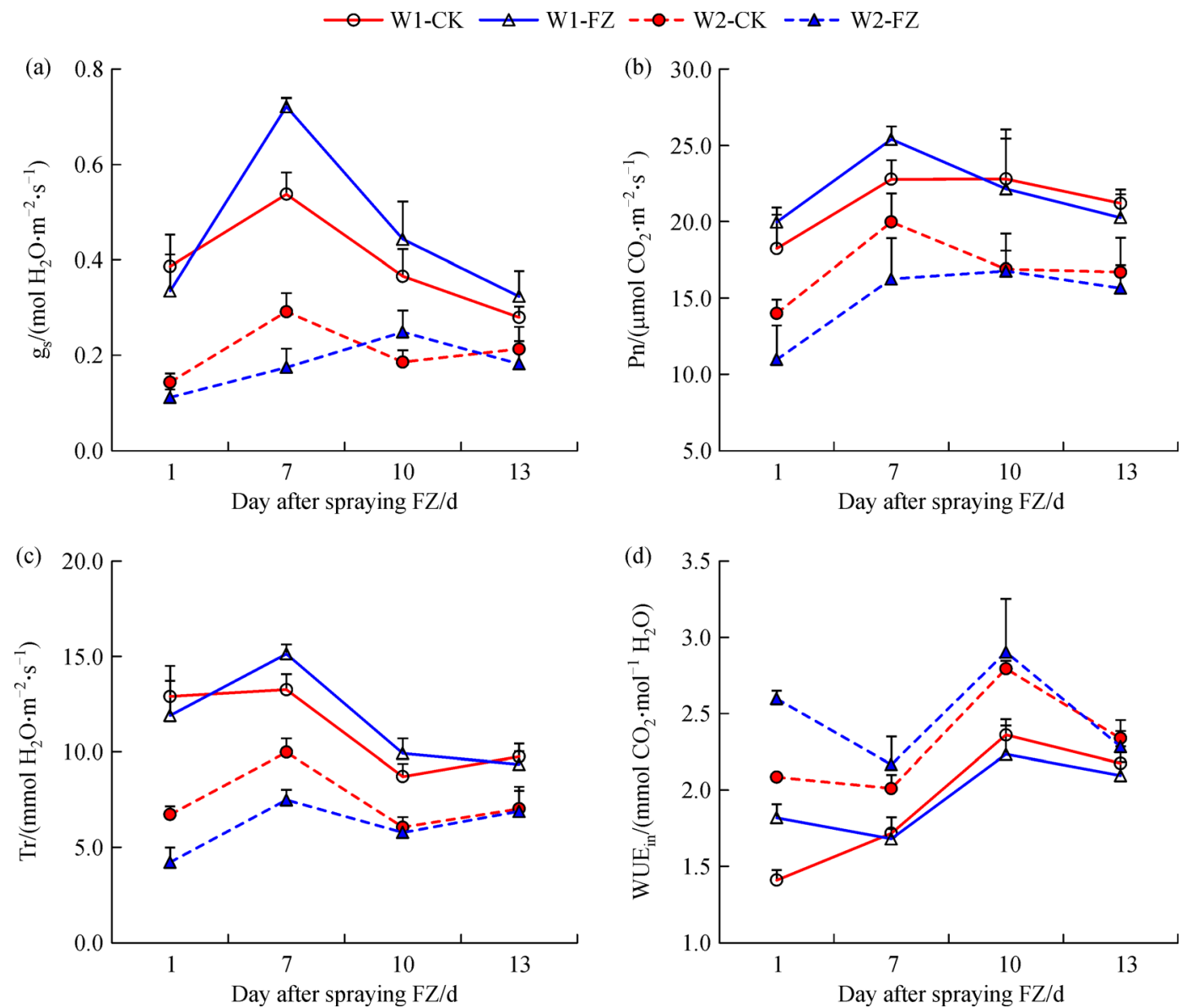

Fig. 3 Effect of foliar application of antitranspirant, FZ, at the pod bearing stage on leaf stomatal conductance $\left(g_{s}\right)(a)$, photosynthetic rate $(\mathrm{Pn})(\mathrm{b})$, transpiration rate $(\mathrm{Tr})(\mathrm{c})$, and instantaneous water use efficiency (WUE $\left.\mathrm{E}_{\text {in }}\right)(\mathrm{d})$ of soybean at different times after spraying. $\mathrm{W} 1$, locally-used irrigation rate; $\mathrm{W} 2$, low irrigation rate; $\mathrm{CK}$, water.

(a)

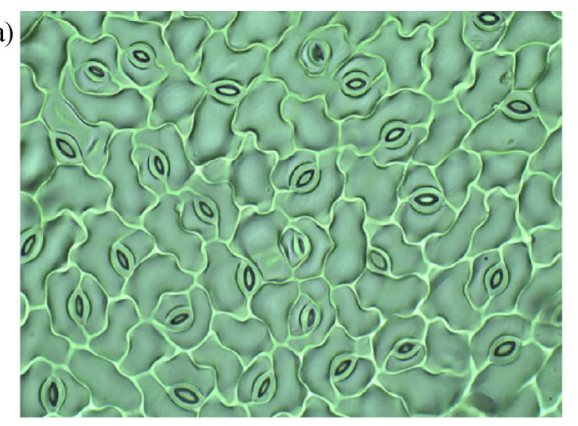

(c)

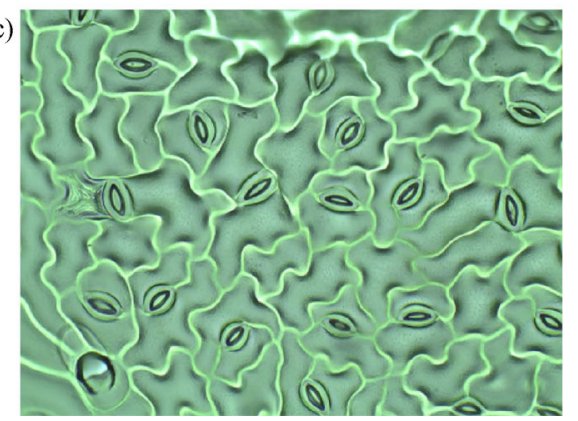

(b)

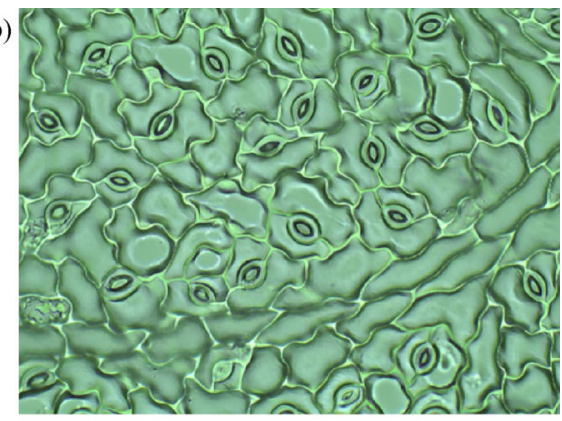

(d)

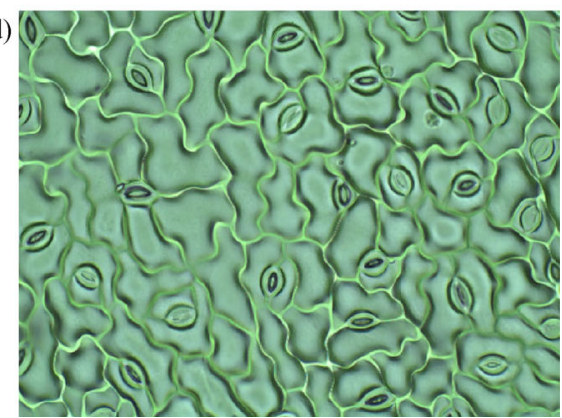

Fig. 4 Representative biomicroscope images of abaxial side of soybean leaves for different treatments. (a) W1-CK; (b) W1-FZ; (c) W2-CK; (d) W2-FZ. W1, locally-used irrigation rate; W2, low irrigation rate; CK, water; FZ, antitranspirant. 

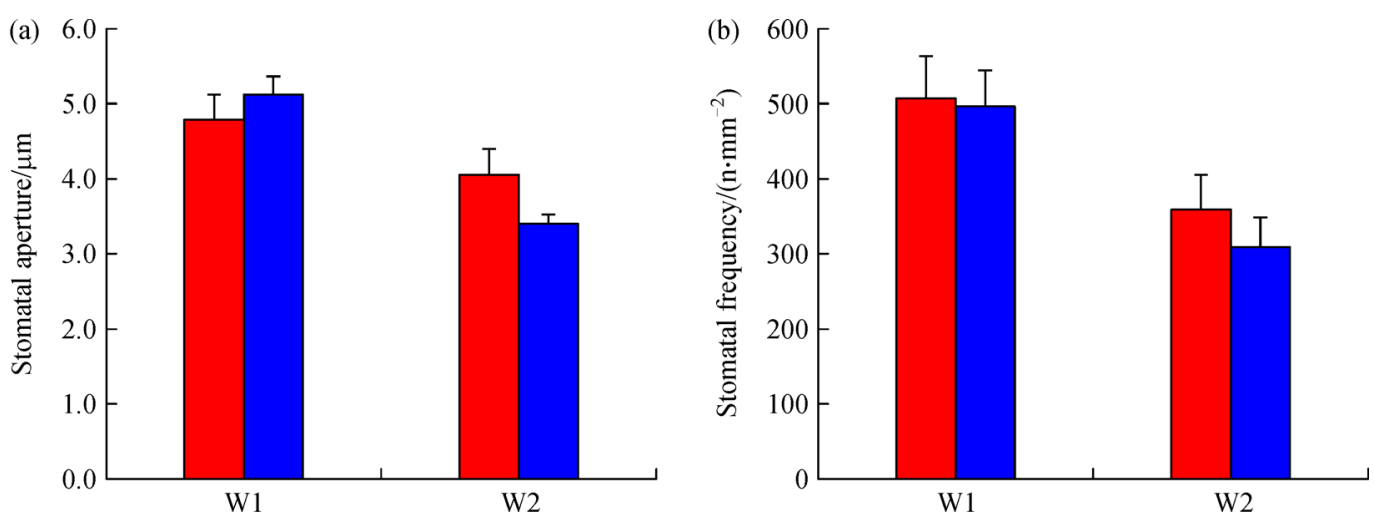

Fig. 5 Effect of foliar application of antitranspirant, FZ, at the early pod filling stage on leaf stomatal aperture (a) and frequency (b) for soybean under different irrigation rates. W1, locally-used irrigation rate; W2, low irrigation rate; CK, water.

Table 3 Effect of foliar application of antitranspirant, FZ, on final biomass, seed yield, harvest index, water consumption and water use efficiency (WUE) of soybean under different irrigation rates

\begin{tabular}{|c|c|c|c|c|c|c|}
\hline Irrigation rate & Treatment & $\begin{array}{l}\text { Final biomass } \\
\text { per plant/g }\end{array}$ & Seed yield $/\left(\mathrm{t} \cdot \mathrm{hm}^{-2}\right)$ & Harvest index $/ \%$ & Water consumption $/ \mathrm{mm}$ & $\mathrm{WUE} /\left(\mathrm{kg} \cdot \mathrm{m}^{-3}\right)$ \\
\hline \multirow[t]{2}{*}{$\overline{\mathrm{W} 1}$} & $\mathrm{CK}$ & $60.79 \pm 2.90 \mathrm{a}$ & $3.02 \pm 0.32 \mathrm{~b}$ & $32.53 \pm 1.31 \mathrm{c}$ & $386.38 \pm 29.39 \mathrm{a}$ & $0.79 \pm 0.12 \mathrm{~b}$ \\
\hline & $\mathrm{FZ}$ & $67.09 \pm 12.57 \mathrm{a}$ & $3.70 \pm 0.09 \mathrm{a}$ & $36.13 \pm 0.04 \mathrm{~b}$ & $384.92 \pm 0.43 \mathrm{a}$ & $0.96 \pm 0.02 \mathrm{a}$ \\
\hline \multirow[t]{2}{*}{ W2 } & CK & $48.42 \pm 5.67 \mathrm{~b}$ & $2.69 \pm 0.26 \mathrm{~b}$ & $39.05 \pm 1.60 \mathrm{a}$ & $287.74 \pm 11.04 \mathrm{~b}$ & $0.93 \pm 0.07 \mathrm{ab}$ \\
\hline & $\mathrm{FZ}$ & $48.34 \pm 9.74 \mathrm{~b}$ & $2.59 \pm 0.11 \mathrm{~b}$ & $39.85 \pm 1.12 \mathrm{a}$ & $298.82 \pm 14.38 \mathrm{~b}$ & $0.87 \pm 0.07 \mathrm{ab}$ \\
\hline \multicolumn{7}{|l|}{ Significance test } \\
\hline Irrigation rate & & $* *$ & $* *$ & $* *$ & $* * *$ & $*$ \\
\hline $\mathrm{FZ}$ & & NS & NS & $*$ & NS & NS \\
\hline Irrigation rate $*$ & $\mathrm{FZ}$ & NS & $*$ & NS & NS & * \\
\hline
\end{tabular}

Note: W1, locally-used irrigation rate; W2, low irrigation rate; CK, water. Different letters in the same column indicate significant differences at $P<0.05$ level. NS, no significance; ***, significance at $P<0.001 ;{ }^{* *}$, significance at $P<0.01 ; *$, significance at $P<0.05$.

probably the reason why total water consumption was not significantly affected. Thus WUE significantly increased under W1. However, under W2, physiological effects including the activities of SOD and POD, Pn, Tr, and stomatal frequency were affected, but applying FZ during the pod bearing stage temporarily decreased stomatal aperture and $\operatorname{Tr}$ by $7 \mathrm{~d}$ after spraying, so the final biomass, seed yield, total water consumption and WUE were not significantly affected. This was probably because severe water deficit affected the absorption of N, P, $\mathrm{K}$ and other trace elements in FZ under W2, leading to the lack of any significant effect on the growth of the soybean plants.

\section{Conclusions}

Under W1, applying FZ during the pod bearing stage increased the activities of SOD and peroxidase POD by $38 \%$ and $33 \%$, respectively, but did not significantly affect leaf $g_{s}, \mathrm{Tr}, \mathrm{Pn}$, stomatal aperture and stomatal frequency.
Seed yield and WUE increased by $23 \%$ and $22 \%$, respectively, after applying FZ three times from pod bearing stage to pod filling stage.

Under W2, leaf $g_{s}$ and $T r$ decreased significantly by $7 \mathrm{~d}$ after spraying FZ during the pod filling stage, but leaf Pn and $W_{U E}$ in were not significantly affected. The stomatal frequency, stomatal aperture, $\mathrm{g}_{\mathrm{s}}$ and $\mathrm{Tr}$ decreased by $16 \%$, $14 \%, 26 \%$ and $14 \%$, respectively, and $\mathrm{WUE}_{\text {in }}$ increased by $1 \mathrm{~d}$ after spraying FZ during the early pod filling stage. However, the final biomass, total water consumption, seed yield and WUE of soybean were not significantly affected by applying FZ three times from pod bearing stage to pod filling stage.

Although the application of the newly developed antitranspirant, FZ, did not have a significant positive effect on soybean under a low irrigation rate, the application of FZ can significantly improve seed yield and water use efficiency of soybean under normal irrigation rates. However, this study was for a single cultivar in one location, so further study of FZ on a wide range of cultivars under different climatic zones and 
irrigation conditions is needed before it is widely used in arid area.

Acknowledgements This study was supported by the National Natural Science Foundation of China $(51621061,91425302)$ and the 111 Program of The Discipline Innovative Engineering Plan (B14002).

Compliance with ethics guidelines Shasha Ji, Ling Tong, Fusheng Li, Hongna $\mathrm{Lu}$, Sien $\mathrm{Li}$, Taisheng $\mathrm{Du}$, and Youjie $\mathrm{Wu}$ declare that they have no conflict of interest or financial conflicts to disclose.

This article does not contain any studies with human or animal subjects performed by any of the authors.

\section{References}

1. Kang S, Hao X, Du T, Tong L, Su X, Lu H, Li X, Huo Z, Li S, Ding $R$. Improving agricultural water productivity to ensure food security in China under changing environment: from research to practice. Agricultural Water Management, 2017, 179: 5-17

2. Jones H. Crop characteristics and the ratio between assimilation and transpiration. Journal of Applied Ecology, 1976, 13(2): 605-622

3. Hafez E, Gharib H. Effect of exogenous application of ascorbic acid on physiological and biochemical characteristics of wheat under water stress. International Journal of Plant Production, 2016, 10(4): 579-596

4. Farooq M, Basra S, Wahid A, Ahmad N, Saleem B. Improving the drought tolerance in rice (Oryza sativa L.) by exogenous application of salicylic acid. Journal Agronomy \& Crop Science, 2009, 195(4): 237-246

5. Zhou B, Guo Z, Liu Z. Effects of abscisic acid on antioxidant systems of Stylosanthes guianensis (Aublet) Sw. under chilling stress. Crop Science, 2005, 45(2): 599-605

6. Hayat Q, Hayat S, Irfan M, Ahmad A. Effect of exogenous salicylic acid under changing environment: a review. Environmental and Experimental Botany, 2010, 68(1): 14-25

7. Ashraf M, Foolad M. Roles of glycine betaine and proline in improving plant abiotic stress resistance. Environmental and Experimental Botany, 2007, 59(2): 206-216

8. Hayat S, Ahmad A. Salicylic acid: a plant hormone. Dordrecht: Springer Netherlands, 2007

9. Zhang X, Zhang X, Liu X, Shao L, Sun H, Chen S. Improving winter wheat performance by foliar spray of ABA and FA under water deficit conditions. Journal of Plant Growth Regulation, 2016, 35(1): 83-96

10. Weerasinghe M, Kettlewell P, Grove I, Hare M. Evidence for improved pollen viability as the mechanism for film antitranspirant mitigation of drought damage to wheat yield. Crop \& Pasture Science, 2016, 67(2): 137-146

11. Park S, Mills S, Moon Y, Waterland N. Evaluation of antitranspirants for enhancing temporary water stress tolerance in bedding plants. HortTechnology, 2016, 26(4): 444-452

12. Faralli M, Grove I, Hare M, Boyle R, Williams K, Corke F, Kettlewell P. Canopy application of film antitranspirants over the reproductive phase enhances yield and yield-related physiological traits of water-stressed oilseed rape (Brassica napus). Crop \& Pasture Science, 2016, 67(7): 751-765
13. Fanourakis D, Giday H, Li T, Kambourakis E, Ligoxigakis E, Papadimitriou M, Strataridaki A, Bouranis D, Fiorani F, Heuvelink E, Ottosen C. Antitranspirant compounds alleviate the milddesiccation-induced reduction of vase life in cut roses. Postharvest Biology and Technology, 2016, 117: 110-117

14. Brillante L, Belfiore N, Gaiotti F, Lovat L, Sansone L, Poni S, Tomasi D. Comparing kaolin and pinolene to improve sustainable grapevine production during drought. PLoS ONE, 2016, 11(6): $\mathrm{e} 0156631$

15. Willmer C, Fricker M. Stomata. London: Springer Science \& Business Media, 1996

16. Gubbels G. Yield and weight per seed in buckwheat after foliar applications of growth-regulators and antitranspirants. Canadian Journal of Plant Science, 1979, 59(3): 857-859

17. Santakumari M, Reddy C, Das V. Alachlor: a new potent antitranspirant on maize plants. In: Proceedings of the Indian Academy of Sciences-Section B. India: Springer, 1977, 143-150

18. Wellburn A R, Ogunkanmi A B, Fenton R, Mansfield T A. Alltrans-farnesol: a naturally occurring antitranspirant? Planta, 1974, 120(3): 255-263

19. Mansfield T. Stomatal behaviour following treatment with auxinlike substances and phenylmercuric acetate. New Phytologist, 1967, 66(3): 325-330

20. Fuehring H. Effect of antitranspirants on yield of grain sorghum under limited irrigation. Agronomy Journal, 1973, 65(3): 348-351

21. Davenport D C, Fisher M A, Hagan R M. Some counteractive effects of antitranspirants. Plant Physiology, 1972, 49(5): 722-724

22. Majbenik O. Responses of stomata of barley and maize to phenylmercuric acetate. Biologia Plantarum, 1970, 12(6): 419423

23. Pasternak D. Some factors responsible for varying effectiveness of stomatal closing antitranspirants. Animal Production Science, 1971, 11(48): 48-52

24. Patil B, De R. Studies on the effect of nitrogen fertilizer, row spacing and use of antitranspirants on rapeseed (Brassica campestris) grown under dryland conditions. Journal of Agricultural Science, 1978, 91 (2): 257-264

25. Srinivasa Rao N. The effects of antitranspirants on leaf water status, stomatal resistance and yield in tomato. Journal of Horticultural Science, 1985, 60(1): 89-92

26. Possingham J, Kerridge G, Bottrill D. Studies with antitranspirants on grapevines (Vitis vinifera var. sultana). Crop \& Pasture Science, 1969, 20(1): 57-64

27. Khan W, Prithiviraj B, Smith D L. Photosynthetic responses of corn and soybean to foliar application of salicylates. Journal of Plant Physiology, 2003, 160(5): 485-492

28. Arfan M, Athar H R, Ashraf M. Does exogenous application of salicylic acid through the rooting medium modulate growth and photosynthetic capacity in two differently adapted spring wheat cultivars under salt stress? Journal of Plant Physiology, 2007, 164 (6): 685-694

29. Hayat S, Hasan S, Fariduddin Q, Ahmad A. Growth of tomato (Lycopersicon esculentum) in response to salicylic acid under water stress. Journal of Plant Interactions, 2008, 3(4): 297304 
30. Travaglia C, Reinoso H, Cohen A, Luna C, Tommasino E, Castillo $\mathrm{C}$, Bottini R. Exogenous ABA increases yield in field-grown wheat with moderate water restriction. Journal of Plant Growth Regulation, 2010, 29(3): 366-374

31. Weaver G, van Iersel M. Antitranspirational efficacy and longevity of abscisic acid and a synthetic abscisic acid analog in pansies (Viola $\times$ wittrockiana). HortScience, 2014, 49(6): 779-784

32. Tucker D J, Mansfield T A. A simple bioassay for detecting "antitranspirant" activity of naturally occurring compounds such as abscisic acid. Planta, 1971, 98(2): 157-163

33. Ogunkanmi A, Tucker D, Mansfield T. Improved bio-assay for abscisic acid and other antitranspirants. New Phytologist, 1973, 72 (2): 277-282

34. Liu L, Cang J, Yu J, Wang X, Huang R, Wang J, Lu B. Effects of exogenous abscisic acid on carbohydrate metabolism and the expression levels of correlative key enzymes in winter wheat under low temperature. Bioscience, Biotechnology, and Biochemistry, 2013, 77(3): 516-525

35. Berkowitz G A, Rabin J. Antitranspirant associated abscisic acid effects on the water relations and yield of transplanted bell peppers. Plant Physiology, 1988, 86(2): 329-331

36. Iriti M, Picchi V, Rossoni M, Gomarasca S, Ludwig N, Gargano M, Faoro F. Chitosan antitranspirant activity is due to abscisic aciddependent stomatal closure. Environmental and Experimental Botany, 2009, 66(3): 493-500

37. Shinohara T, Leskovar D. Effects of ABA, antitranspirants, heat and drought stress on plant growth, physiology and water status of artichoke transplants. Scientia Horticulturae, 2014, 165: 225234

38. Travaglia C, Cohen A, Reinoso H, Castillo C, Bottini R. Exogenous abscisic acid increases carbohydrate accumulation and redistribution to the grains in wheat grown under field conditions of soil water restriction. Journal of Plant Growth Regulation, 2007, 26(3): 285289

39. Goreta S, Leskovar D, Jifon J. Gas exchange, water status, and growth of pepper seedlings exposed to transient water deficit stress are differentially altered by antitranspirants. Journal of the American Society for Horticultural Science, 2007, 132(5): 603-610

40. Seki M, Umezawa T, Urano K, Shinozaki K. Regulatory metabolic networks in drought stress responses. Current Opinion in Plant Biology, 2007, 10(3): 296-302

41. Russo V, Diaz-Perez J. Kaolin-based particle film has no effect on physiological measurements, disease incidence or yield in peppers. HortScience, 2005, 40(1): 98-101

42. Cantore V, Pace B, Albrizio R. Kaolin-based particle film technology affects tomato physiology, yield and quality. Environmental and Experimental Botany, 2009, 66(2): 279-288

43. Boari F, Donadio A, Pace B, Schiattone M, Cantore V. Kaolin improves salinity tolerance, water use efficiency and quality of tomato. Agricultural Water Management, 2016, 167: 29-37

44. Abou-Khaled A, Hagan R, Davenport D. Effects of kaolinite as a reflective antitranspirant on leaf temperature, transpiration, photosynthesis, and water-use efficiency. Water Resources Research, 1970, 6(1): 280-289

45. Palliotti A, Panara F, Famiani F, Sabbatini P, Howell G, Silvestroni O, Poni S. Postveraison application of antitranspirant di-1-p- menthene to control sugar accumulation in sangiovese grapevines. American Journal of Enology and Viticulture, 2013, 64(3): 378-385

46. del Amor F M, Cuadra-Crespo P, Walker D J, Cámara J M, Madrid R. Effect of foliar application of antitranspirant on photosynthesis and water relations of pepper plants under different levels of $\mathrm{CO}_{2}$ and water stress. Journal of Plant Physiology, 2010, 167(15): 12321238

47. Ludwig N, Cabrini R, Faoro F, Gargano M, Gomarasca S, Iriti M, Picchi V, Soave C. Reduction of evaporative flux in bean leaves due to chitosan treatment assessed by infrared thermography. Infrared Physics \& Technology, 2010, 53(1): 65-70

48. Abdullah A, Aziz M, Siddique K, Flower K. Film antitranspirants increase yield in drought stressed wheat plants by maintaining high grain number. Agricultural Water Management, 2015, 159: 1118

49. Mohawesh O, Al-Absi K, Tadros M. Effect of antitranspirant application on physiological and biochemical parameters of three orange cultivars grown under progressive water deficit. Advances in Horticultural Science, 2010, 24(3): 183-194

50. Kettlewell P, Heath W, Haigh I. Yield enhancement of droughted wheat by film antitranspirant application: rationale and evidence. Agricultural Sciences, 2010, 1(3): 143-147

51. Weerasinghe M, Kettlewell P, Grove I, Hare M. Physiological mechanisms underlying the yield increase of droughted wheat from film antitranspirant application. Aspects of Applied Biology, 2010, (105): 25-29

52. Kettlewell P. Waterproofing wheat-a re-evaluation of film antitranspirants in the context of reproductive drought physiology. Outlook on Agriculture, 2014, 43(1): 25-29

53. Khalil S, Hussein M, Da Silva J. Roles of antitranspirants in improving growth and water relations of Jatropha curcas L. grown under water stress conditions. Plant Stress, 2012, 6(1): 49-54

54. Moftah A, Al-Humaid A R. Effects of antitranspirants on water relations and photosynthetic rate of cultivated tropical plant (Polianthes tuberosa L.). Polish Journal of Ecology, 2005, 53(2): 165-175

55. Ran H, Kang S, Li F, Tong L, Ding R, Du T, Li S, Zhang X. Performance of AquaCrop and SIMDualKc models in evapotranspiration partitioning on full and deficit irrigated maize for seed production under plastic film-mulch in an arid region of China. Agricultural Systems, 2017, 151: 20-32

56. Ran H, Kang S, Li F, Tong L, Du T. Effects of irrigation and nitrogen management on hybrid maize seed production in northwest China. Frontiers of Agricultural Science and Engineering, 2016, 3(1): 55-64

57. Jiang X, Kang S, Tong L, Li F. Modification of evapotranspiration model based on effective resistance to estimate evapotranspiration of maize for seed production in an arid region of northwest China. Journal of Hydrology, 2016, 538: 194-207

58. Agboma P, Sinclair T, Jokinen K, Peltonen-Sainio P, Pehu E. An evaluation of the effect of exogenous glycinebetaine on the growth and yield of soybean: timing of application, watering regimes and cultivars. Field Crops Research, 1997, 54(1): 51-64

59. Weyers J, Johansen L. Accurate estimation of stomatal aperture from silicone rubber impressions. New Phytologist, 1985, 101(1): 109-115 
60. Li H. Experimental guidance for plant physiology. Beijing: Higher Education Press, 2000 (in Chinese)

61. Mao H. Research of soybean water requirement and schedule with drip irrigation. Agricultural Research in the Arid Areas, 2009, 27(5): 112-117 (in Chinese)
62. Evans J. Photosynthesis and nitrogen relationships in leaves of $\mathrm{C}_{3}$ plants. Oecologia, 1989, 78(1): 9-19

63. Bowler C, Montagu M, Inze D. Superoxide dismutase and stress tolerance. Annual Review of Plant Biology, 1992, 43(1): 83116 